\title{
A comparison of nitrogen fixation in genotypes of groundnut (Arachis hypogaea L.) using ${ }^{15} \mathrm{~N}$-isotope dilution *
}

\author{
K. E. Giller ${ }^{1 * *}$, P. T. C. Nambiar ${ }^{2}$, B. Srinivasa Rao $^{2}$, P.J. Dart ${ }^{1 * * *}$ and J. M. Day ${ }^{1}$ \\ ${ }^{1}$ Soil Microbiology Department, Rothamsted Experimental Station, Harpenden, AL52JQ, UK \\ ${ }^{2}$ International Crops Research Institute for the Semi-Arid Tropics (ICRISAT), Patancheru P. O., 502324, Andhra Pradesh, India
}

Summary. Nitrogen fixation in seven groundnut genotypes was measured by ${ }^{15} \mathrm{~N}$-isotope dilution using a non-nodulating cultivar of groundnut as the nonfixing reference plant. Nitrogen fixation varied between $100 \mathrm{~kg} \mathrm{Nha}^{-1}$ in genotype $\mathrm{J}-11$ and $153 \mathrm{~kg}$ $\mathrm{N}$ ha ${ }^{-1}$ in Robut 33-1. The amount of plant-available soil $\mathrm{N}$ was small, so that $86 \%-92 \%$ of plant nitrogen was derived from $\mathrm{N}_{2}$-fixation. Thus differences in $\mathrm{N}_{2-}$ fixation between genotypes closely reflected differences in their total $\mathrm{N}$ accumulation.

Key words: $\mathrm{N}_{2}$-fixation - Arachis hypogaea $-{ }^{15} \mathrm{~N}$ isotope dilution - Groundnut - Rhizobium inoculation - Plant available soil N

Groundnut (Arachis hypogaea L.) is often grown in soils poor in nitrogen, but responds little to added fertilizer. Substantial variation between genotypes of groundnut in nodulation and acetylene reduction activity has been found (Arunachalam et al. 1978; Elkan et al. 1980; Nambiar and Dart 1980), but the amounts of nitrogen fixed in the field have not been determined using ${ }^{15} \mathrm{~N}$-labelled fertilizer.

In work described here, the ${ }^{15} \mathrm{~N}$-isotope dilution method has been used to estimate the amount of $\mathrm{N}_{2}$ fixed by several groundnut genotypes in the field. A

\footnotetext{
* ICRISAT Journal Article no. 600 Present addresses:

** Department of Biochemistry, Physiology and Soil Science, Wye College, University of London, Wye, Ashford, Kent, TN255AH, UK

*** Research School of Biological Sciences, Australian National University, P.O. Box 475, Canberra, ACT2601, Australia
}

Offprint requests to: K. E. Giller non-nodulating groundnut genotype was used as a control, as this was considered more likely to match the rooting and nitrogen accumulation patterns of the nodulated genotypes than non-legume crops, and thus reduce possible errors (Witty 1983). Growth of the non-nodulating groundnut is poor in the absence of a large supply of available N (ICRISAT 1981), and N fertilizer was applied to ensure reasonable growth of the control crop.

\section{Materials and methods}

The experiment was carried out at the ICRISAT centre, Patancheru, A. P., India. A cover crop of Zea mays L. was grown (and above-ground plant parts removed) in the previous season to deplete the available $\mathrm{N}$ in the Alfisol soil. The experiment was sown on 2. 12. 81 with six replicate blocks $(13.5 \times 18 \mathrm{~m})$. The control treatment of the non-nodulating groundnut, fertilized with $100 \mathrm{~kg} \mathrm{~N} \mathrm{ha}^{-1}$, was located centrally in each block and other treatments randomized around it in order to maintain the closest proximity possible between each treatment and the control. The $\mathrm{N}_{2}$-fixing treatments were cultivars J11, Gangapuri (Spanish types), PI 259747 (Valencia type), NC 17, ICGS22 and Robut 33-1 (Virginia types), non-inoculated, and Robut 33-1 inoculated with Rhizobium strain NC92, all fertilized with $10 \mathrm{~kg} \mathrm{~N} \mathrm{ha}^{-1}$. A further treatment, in which the non-nodulating groundnut was grown with $200 \mathrm{~kg} \mathrm{~N}$ $\mathrm{ha}^{-1}$, was included to check if the rate of nitrogen addition had an effect on the estimate of the available soil- $N$ pool. Seeds were spaced at $10-\mathrm{cm}$ intervals within $75-\mathrm{cm}$ rows and treatment plots consisted of six rows of $6 \mathrm{~m}\left(27 \mathrm{~m}^{2}\right)$.

All fertilizer was applied as ammonium sulphate, with ${ }^{15} \mathrm{~N}-\mathrm{la}-$ belled fertilizer applied to central subplots $\left(4.5 \mathrm{~m}^{2}\right)$ of each treatment with enrichments of 5.123 atom $\%{ }^{15} \mathrm{~N}$ excess $\left(10 \mathrm{~kg} \mathrm{~N} \mathrm{ha}^{-1}\right)$, 0.512 atom $\%{ }^{15} \mathrm{~N}$ excess $\left(100 \mathrm{~kg} \mathrm{~N} \mathrm{ha}^{-1}\right)$ and 0.256 atom $\%{ }^{15} \mathrm{~N}$ excess ( $\left.200 \mathrm{~kg} \mathrm{~N} \mathrm{ha}^{-1}\right)$. The experiment was irrigated at sowing and as required (about 10- to 15-day intervals), using Perfor overhead irrigation until the plants were 39 days old, and subsequently furrow irrigation was employed.

All plots were harvested 89 days after sowing. Two metres of each of the central two rows of the ${ }^{15} \mathrm{~N}$ subplots $\left(3 \mathrm{~m}^{2}\right)$ were removed for chemical analysis, and a further sample from $14.25 \mathrm{~m}^{2}$ was taken for yield and dry matter estimates. Fresh plant material was weighed on site and a subsample taken to estimate water con- 
Table 1. $\mathrm{N}_{2}$-fixation by groundnut cultivars estimated by isotope dilution using a non-nodulating genotype $\left(100 \mathrm{~kg} \mathrm{~N} \mathrm{ha}^{-1}\right)$ as a reference plant

\begin{tabular}{|c|c|c|c|c|c|c|c|c|}
\hline Treatment & $\begin{array}{l}\text { Total dry matter } \\
\left(\mathrm{kg} \mathrm{ha}^{-1}\right)\end{array}$ & $\begin{array}{l}\text { Pod yield } \\
\left(\mathrm{kg} \mathrm{ha}^{-1}\right)\end{array}$ & $\begin{array}{l}\text { Total N } \\
\left(\mathrm{kg} \mathrm{ha}^{-1}\right)\end{array}$ & $\begin{array}{l}\text { Atom } \%{ }^{15} \mathrm{~N} \\
\text { excess }\end{array}$ & $\begin{array}{l}\% \text { Fertilizer } \\
\text { recovery }\end{array}$ & $\begin{array}{l}\mathrm{N} \text { from soil } \\
\left(\mathrm{kg} \mathrm{ha}^{-1}\right)\end{array}$ & $\begin{array}{l}\mathrm{N} \text { from fixation } \\
\left(\mathrm{kg} \mathrm{ha}^{-1}\right)\end{array}$ & $\begin{array}{l}\% \mathrm{~N} \\
\text { fixed }\end{array}$ \\
\hline $\begin{array}{l}\text { Robut 33-1 } \times \\
\quad \text { NC-92 }\end{array}$ & 5870 & 3000 & 165 & 0.028 & 7.2 & 12 & 152 & 92 \\
\hline Robut 33-1 & 5630 & 2990 & 162 & 0.024 & 7.3 & 12 & 149 & 92 \\
\hline $\mathrm{NC}-17$ & 5200 & 2400 & 150 & 0.031 & 9.0 & 16 & 133 & 89 \\
\hline ICGS-22 & 4910 & 2230 & 127 & 0.023 & 5.6 & 10 & 117 & 92 \\
\hline Gangapuri & 4790 & 2290 & 131 & 0.032 & 8.2 & 14 & 116 & 89 \\
\hline PI-259747 & 5250 & 1960 & 126 & 0.039 & 9.7 & 16 & 109 & 86 \\
\hline $\mathrm{J}-11$ & 4330 & 1830 & 111 & 0.029 & 6.1 & 11 & 100 & 90 \\
\hline $\begin{array}{l}\text { Non-nod } \\
100 \mathrm{~kg} \mathrm{~N} \mathrm{ha}^{-1}\end{array}$ & 2570 & 920 & 41 & 0.193 & 15.6 & 25 & $0^{\mathrm{a}}$ & $0^{\mathrm{a}}$ \\
\hline $\begin{array}{l}\text { Non-nod } \\
200 \mathrm{~kg} \mathrm{~N} \mathrm{ha}^{-1}\end{array}$ & 3480 & 1120 & 60 & 0.137 & 16.0 & 27 & 1.2 & $1.2^{\mathrm{a}}$ \\
\hline SE & 148 & 95 & 4.5 & 0.0028 & 0.99 & 1.53 & 4.8 & 1.0 \\
\hline
\end{tabular}

Apparent soil $\mathrm{N}$ pool (A-value) estimated to be $163 \mathrm{~kg} \mathrm{ha}^{-1}$ using the non-nod $\times 100 \mathrm{~kg} \mathrm{~N}^{-1}$ treatment and $175 \mathrm{~kg} \mathrm{ha}^{-1} \mathrm{using}$ the non-nod $\times 200 \mathrm{~kg} \mathrm{~N} \mathrm{ha}^{-1}$ treatment

a Values excluded from statistical calculations

tent. Plants sampled from $\mathrm{N}$ subplots were separated into shoot, husk and seed fractions for analysis. Nitrogen content was determined by Kjeldahl digestion and by an automated indophenol blue method (Anon 1978). Petroleum ether (BP $40^{\circ} \mathrm{C}$ ) was used to remove excess oil from the seed before digestion. Nitrogen in the digests was concentrated by a Conway microdiffusion technique (Conway 1939) and ${ }^{15} \mathrm{~N}$ enrichments measured using a Micromass 622 mass spectrometer (VG Isogas, Norwich, Cheshire, UK). Amounts of nitrogen fixed were calculated using equations given by Witty (1983).

\section{Results and discussion}

The non-nodulating groundnut produced $1000 \mathrm{~kg}$ ha ${ }^{-1}$ more dry matter with $200 \mathrm{~kg} \mathrm{~N}^{-1}$ than with $100 \mathrm{~kg} \mathrm{~N}$ (Table 1). Although the two control crops accumulated different amounts of nitrogen, estimates of the apparent soil $\mathrm{N}$ pool calculated from their ${ }^{15} \mathrm{~N}$ enrichments were similar. Fertilizer recovery $(\%)$ and the amount of soil nitrogen taken up were not significantly different between the two fertilizer treatments of the non-nodulating groundnut.

Fertilizer recovery $(\%)$ was less in all nodulated groundnut lines than in the control treatments. Estimates of nitrogen fixed ranged from $153 \mathrm{~kg} \mathrm{ha}^{-1}$ in Robut 33-1 (the recommended cultivar for cultivation in Andhra Pradesh) to $100 \mathrm{~kg} \mathrm{ha}^{-1}$ in $\mathrm{J} 11$. In this trial, inoculation of Robut 33-1 with cowpea Rhizobium strain NC92, a combination often effective in increasing yields (Nambiar et al. 1982), did not increase the yield significantly above that of uninoculated Robut 33-1. Lack of a yield increase was probably due to NC92 having been used as an inoculum in this field previously. Of the other groundnut genotypes tested here, $\mathrm{NC17}$ was the only line which fixed a similar amount of nitrogen to Robut 33-1. The ranking of genotypes confirms earlier findings that Virginia types generally fix more nitrogen that Valencia or Spanish types (Nambiar et al. 1980).

Nodulated groundnut genotypes absorbed only a small proportion of the applied nitrogen and there was some small, but significant, variation between genotypes in percentage fertilizer recovery (overall mean $7.6 \% \pm 0.52 \%$ ). With the irrigation methods employed, it is unlikely that the low fertilizer recovery was due to leaching losses of the fertilizer; it probably reflects a poor ability of groundnut to absorb fertilizer (Nambiar et al. 1986). Non-nodulating groundnut grown without added nitrogen only accumulates $20-30 \mathrm{~kg} \mathrm{~N} \mathrm{ha}^{-1}$, and such genotypes require at least $300 \mathrm{~kg} \mathrm{~N} \mathrm{ha}^{-1}$ in fertilizer to produce maximal yield (ICRISAT 1982). If the soil nitrogen pool is less than $200 \mathrm{~kg} \mathrm{~N}^{-1}$, as in this soil which is typical of those where groundnut is grown, nodulated genotypes would rarely derive more than $16 \mathrm{~kg} \mathrm{~N} \mathrm{ha}^{-1}$ from the soil. Indeed sorghum (Sorghum bicolor (L.) Moench), which has a deeper, more extensive rooting system, typically removes only $30-55 \mathrm{~kg} \mathrm{ha}^{-1}$ soil nitrogen when grown on alfisol soils (ICRISAT 1982). As groundnut crops commonly accumulate more than $100 \mathrm{~kg} \mathrm{~N} \mathrm{ha}^{-1}$, they therefore contain a relatively small contribution from the soil and a high proportion of plant $\mathrm{N}$ from fixation (a range of $86 \%-92 \%$ $\mathrm{N}$ fixed; Table 1). Hence, when groundnut is grown without fertilizer $\mathrm{N}$, the total nitrogen accumulation is likely to be a good indication of the plant benefit from $\mathrm{N}_{2}$-fixation. 


\section{References}

Anon (1978) Analysis of crops, soils and fertilizers. Soil and Plant Nutrition Department, Rothamsted Experimental Station, Harpenden, England

Arunachalam V, Pungle GD, Dutta M, Nambiar PTC, Dart PJ (1984) Efficiency of nitrogenase activity and nodule mass in predicting the relative performance of genotypes assessed by a number of characters in groundnut (Arachis hypogaea). Exp Agric 20:303-310

Conway EJ (1939) Microdiffusion analysis and volumetric error. Crosby Lockwood, London

Elkan GH, Wynne JC, Schneeweis JJ, Isleib TG (1980) Nodulation and nitrogenase activity of peanuts isolated with single strain isolates of Rhizobium. Peanut Sci 7:95-97

ICRISAT (1981) Annual report. ICRISAT, Patancheru A. P., India, p 187

ICRISAT (1982) Annual report. ICRISAT, Patancheru A. P., India, p 249
Nambiar PTC, Rego TJ, Srinivasa Rao B (1986) Comparison of the requirements and utilization of nitrogen by genotypes of sorghum (Sorghum bicolor (L.) Moench), and nodulating and nonnodulating groundnut (Arachis hypogaea L.). Field Crops Res $15: 165-179$

Nambiar PTC, Dart PJ (1980) Studies on nitrogen fixation in groundnut at ICRISAT. In: Gibbons RW (ed) Proceedings of the International Symposium on the Groundnut, ICRISAT, Patancheru A. P., India, pp 110-124

Nambiar PTCN, Dart PJ, Srinivasa Rao B, Ravi-Shankar HN (1982) Response of groundnut (Arachis hypogaea) to inoculation. In: Graham PH, Harris S (eds) Biological nitrogen fixation technology for tropical agriculture. CIAT, Cali, Colombia, pp $241-248$

Witty JF (1983) Estimating $\mathrm{N}_{2}$-fixation in the field using ${ }^{15} \mathrm{~N}$-labelled fertilizer: some problems and solutions. Soil Biol Biochem $15: 631-639$

Received July 24, 1986 